\title{
Protein Phosphatase Slingshot Homolog 2
}

National Cancer Institute

\section{Source}

National Cancer Institute. Protein Phosphatase Slingshot Homolog 2. NCI Thesaurus.

Code C114426.

Protein phosphatase Slingshot homolog 2 (1423 aa, $\sim 158 \mathrm{kDa}$ ) is encoded by the human $\mathrm{SSH} 2$ gene. This protein plays a role in both the regulation of actin polymerization and the dephosphorylation of proteins. 